\title{
Adopting cover crops and buffer strips to reduce nonpoint source pollution: Understanding farmers' perspectives in the US Northern Great Plains
}

\author{
T. Wang, Y. Fan, Z. Xu, S. Kumar, and B. Kasu
}

\begin{abstract}
Agricultural nonpoint source pollution has been identified as a major cause of water quality impairments. Utilizing survey data from the Northern Great Plains, this paper provides a better understanding of farmers' perceptions on water quality issues in their local areas. Excessive algal bloom and aquatic plants were among producers' top water quality concerns in North Dakota, South Dakota, and Nebraska. Fertilizers/pesticides were perceived as either not a problem $(28.7 \%)$ or a slight problem $(43.7 \%)$ when it comes to the water pollution sources. While only $17.2 \%$ of the respondents indicated agreement upon paying taxes to help protect the local water quality, $43.5 \%$ agreed to implement conservation practices (CPs) at some cost, and $70.1 \%$ agreed to implement CPs at no direct cost to farmers to improve water quality. This paper examined the factors associated with the adoption of cover crops and buffer strips. We found that producers' adoption decisions of cover crops largely hinged on farm characteristics and management variables, such as land ownership, farm size, livestock ownership, and adoption status of other farm management practices, while water quality information and producer perceptions affected the adoption decisions of both cover crops and buffer strips. To further promote $\mathrm{CP}$ adoption and reduce water pollution, our results highlighted the importance of both monetary incentives and outreach efforts that disseminate information on water pollution status and pollution sources, as well as technical support on CPs suitable for the farm.
\end{abstract}

Key words: adoption—best management practice-buffer strip-cover crop-nonpoint source pollution

\begin{abstract}
Agricultural nonpoint source pollution has been identified as a major cause of water quality impairments in the United States (USEPA 2017). Increased fertilizer use, while contributing to increased productivity, leads to pollution of aquatic ecosystems when not absorbed by the plants (Savci 2012). Nitrogen (N) is often regarded as one of the best inputs in terms of cost-effectiveness; therefore, its over-application is common (Pikul et al. 2005; Scharf et al. 2005). With plant nutrient uptake as low as $30 \%$, the unabsorbed $\mathrm{N}$ is susceptible to leaching and surface runoff (Legg and Meisinger 1982).
\end{abstract}

Soil, when left without plant coverage for an extended time period, can be eroded at an accelerated rate (Montgomery 2007). Rainwater carries soil sediments, as well as the nutrients and agricultural chemicals that attach to the soil particles, to nearby water bodies. A high nitrate $\left(\mathrm{NO}_{3}^{-}\right)$level in water in return causes various aesthetic, health, and economic issues, including rapid growth of aquatic plants and algal bloom, decreased fish population, polluted swimming and boating areas, potential health risks, and eroded tourism revenues (Bhargava 1994; Suplee et al 2009; Ward 2009; Khan et al. 2018; Nieman et al. 2018).

Received November 11, 2020; Revised February 6, 2021; Accepted March 18, 2021; Published online July 26, 2021.
By making decisions on selecting conservation practices (CPs), farmers play a critical role in reducing the nonpoint source pollutants and their negative, unintended consequences. Cover crops have been identified as an effective practice that can improve water quality by providing a protection cover to the soil. In addition to reducing the energy of rainfall on soils, cover crops also help improve soil infiltration and water storage capacity. As a return, cover crops can decrease runoff by up to $80 \%$ and reduce sediment loss of between $40 \%$ and $96 \%$ (Blanco-Canqui et al. 2015). Cover crops reduce runoff of phosphorus $(\mathrm{P})$ that is contained in both soluble runoff and eroded soil particles (Zeimen et al. 2006). Cover crops can also absorb excessive soil $\mathrm{N}$ during spring when the crop utilization rate is low (Strock et al. 2004; Tonitto et al. 2006; Castellano et al. 2012). For example, rye (Secale cereale L.) cover crops can scavenge between $25 \%$ and $100 \%$ of residual $\mathrm{N}$ from cornfields (Zea mays L.), thereby preventing the nutrients from washing into nearby waterbodies (Clark 2012). In addition to the aforementioned off-site social benefits, cover crops also possess on-site farm benefits such as enhancing cash crop yield through soil health improvement (Carlson and Anderson 2012; CTIC 2014, 2015; Dagel et al. 2014), suppressing weeds, reducing pest pressures (Montgomery 2007; CTIC 2017), and generating additional revenue from haying and grazing (Lichtenberg 2004).

Even with the well-documented benefits, challenges remain due to the difficulties in cover crop establishment, up-front economic costs, unpredictable yield benefits, and variations in weather and soil conditions (Bergtold et al.2012; CTIC 2015). One of farmers' con-

Tong Wang is an assistant professor and advanced production specialist in the Ness School of Management and Economics (NSME) at South Dakota State University, Brookings, South Dakota. Yubing Fan is a postdoctoral research associate at Texas A\&M Agrilife Research, Vernon, Texas. Zheng $X u$ is an assistant professor in the Department of Mathematics and Statistics, Wright State University, Fairborn, Ohio. Sandeep Kumar is an associate professor in the Department of Agronomy, Horticulture and Plant Sciences at South Dakota State University, Brookings, South Dakota. Bishal Kasu worked as a postdoctoral research associate in the Department of Agronomy, Horticulture and Plant Sciences at South Dakota State University, Brookings, South Dakota. 
cerns when considering cover crop adoption is successful establishment of cover crops to get the associated benefits. According to a US nationwide cover crop survey (CTIC 2017), $73 \%$ of the respondents planted cover crops after harvesting cash crops. Regions with a short growing season have a short window to plant cover crops because cover crops that are not winter hardy, such as legumes, need at least four to six weeks to obtain full benefits (MCCC 2015). In addition, the benefits of cover crops are also contingent on other implemented CPs such as no-till, as long-term no-till use can strengthen the soil benefits of cover crops while tillage weakens such benefits (Hoorman 2009; Clark 2012). Despite the cost-share programs, short-term cover crop use generally reduces farm profitability (Plastina et al. 2020). Risks and extra costs render cover crop adoption potentially more challenging than the other recommended nutrient management practices (Fan et al. 2020).

Buffer strips, also referred to as buffer zones, riparian buffers, filter strips, and grassed waterways, are well-established agricultural practices that effectively trap sediment in the field and reduce the nonpoint source pollutants from agricultural production (Dosskey 2001; Hebblethwaite and Somody 2008; Stutter et al. 2012; USDA NRCS n.d.). The use of perennial grasses or trees as buffer strips between agricultural fields and water bodies can effectively intercept water flow and reduce soil sediments, nutrients, and chemicals from runoff (Castelle et al. 1994; Blanco-Canqui et al. 2004; Dabney et al. 2006). Previous studies have shown that buffer strips' sediment trapping efficiencies vary between $41 \%$ and $100 \%$ (Helmers et al. 2008; Liu et al. 2008), and $\mathrm{NO}_{3}^{-}$reduction efficiencies between 25\% and 100\% (Daniels and Gilliam 1996; Simpkins et al. 2002).

Relative to cover crops, the benefits offered by buffer strips are primarily off-site. In addition to the establishment and maintenance costs of buffer vegetation, buffer strips on cropland also incur the opportunity cost of foregone crop production, and those on pastureland also incur forgone livestock production and livestock exclusion (fencing) cost (Liu et al. 2011). Based on six counties in the Lower Kentucky River Basin, Liu et al. (2011) estimated the total annualized costs of riparian buffers for cropland varied between US\$110 and US\$621 $\mathrm{ac}^{-1}$ (US\$272 and US $\$ 1,535 \mathrm{ha}^{-1}$ ), while those for pastureland ranged between US\$105 and US\$128 $\mathrm{ac}^{-1}$ (US\$259 and US\$316 ha $\mathrm{ha}^{-1}$ ). Despite the offered financial incentives by programs such as Conservation Reserve Program (CRP) and Environmental Quality Incentives Program (EQIP), additional costs and lost production remain the major concerns regarding buffer strip adoption. Other constraints to buffer strip adoption include increased labor and management costs and uncertain economic circumstances (Liu et al. 2008; Klapproth and Johnson 2009; Rhodes et al. 2018).

Both cover crops and buffer strips are highly recommended conservation practices to reduce soil erosion and nutrient leaching, and thereby reducing the pollution of groundwater and surface water.Yet the adoption rates of these practices remain low. For example, a study utilizing farmer survey data in Maumee watershed of Ohio found that even though $42.3 \%$ of farmers used cover crops sometimes, only $7.9 \%$ planted cover crops all the time, while $29.2 \%$ and $34.7 \%$ reported always using grass waterways and filter strips, respectively (Wilson et al. 2013). The relatively low adoption rates further motivate studies that examine influencing factors of farmers' adoption decisions, which are likely to vary across different conservation practices (Knowler and Bradshaw 2007; Prokopy et al. 2008, 2019). This study aims to understand the motivating and constraining factors that affect farmers' adoption behavior of two conservation practices-cover crops and buffer strips. Cover crops generate a combination of on- (private) and off-site (public) benefits, while buffer zones primarily target the off-site (public) benefits. As the recommended policy mechanisms that encourage the two practices differ (Pannell 2008), we examine the potential disparities in the influencing factors that affect adoption decisions of the two practices.

We carried out a mail survey among farmers in the Northern Great Plains of the United States, comprising North Dakota, South Dakota, and Nebraska. Agricultural production is the major contributor of the region's economy, yet a lack of adequate conservation practices has greatly compromised the beneficial uses of local water bodies. In North Dakota, 68\% of the 4,864 assessed river and stream miles $(7,828 \mathrm{~km})$ were either threatened for or not fully supporting aquatic life use as of 2018 (NDDH 2019). Similarly, $78 \%$ of the 5,875 stream miles $(9,455 \mathrm{~km})$ in
South Dakota were found not supporting one or more beneficial uses of the water during the 2014 to 2019 period (SDDENR 2020). Among 13 major river basins in Nebraska, the basin at the best condition had $59 \%$ of the streams in good condition, and the basin that presented most concerns only had $14 \%$ of the streams in good condition (NDEQ 2016). A site-specific conservation system approach is needed to reduce nonpoint source pollution and improve water quality in this region. Therefore, the main objectives of this study are to (1) understand farmers' perceptions on water pollution sources and measures they desire to adopt to improve water quality; (2) understand the current adoption status of two best management practices, namely cover crops and buffer strips; (3) explore a combination of sociodemographic factors that are likely to influence cover crop and buffer strip adoption; and (4) identify ways to improve outreach and engagement in order to increase future conservation practice adoption.

\section{Materials and Methods}

Empirical Model. The outcome variables, cover crop adoption and buffer strip adoption, are binary in nature. They are denoted as 1 when a farmer adopts the practice, and 0 otherwise. Due to the potential correlation between the two CP adoption decisions, we first estimated a bivariate logit model for the joint adoption decisions of cover crops and buffer strips. We found the correlation coefficient between the errors when jointly modeling the two latent variables for adoption decisions was not significantly different from 0 , which means cover crop and buffer strip adoption decisions are not interrelated. Therefore, logistic regression models were employed in the analysis to explain the adoption behaviors of two CPs separately using multiple explanatory variables (Hastie et al. 2009; Greene 2018).

Logistic regression is specified as a latent variable model. Let $Y_{i}$ and $Y_{i}^{*}$ denote the actual adoption behavior and the continuous latent adoption tendency for individual $i$, respectively. The actual adoption occurs if the adoption tendency is positive, and no adoption will occur otherwise, as indicated in equation 1 :

$Y_{i}=\left\{\begin{array}{l}1, \text { if } Y_{i}^{*}>0 \\ 0, \text { otherwise } .\end{array}\right.$

Denote $X_{i}=\left(X_{i 1}, X_{i 2}, \ldots, X_{i p}\right)^{T}$ as the vector of explanatory variables for individual $i$. The 
latent adoption tendency variable $Y_{i}^{*}$ is modeled as in equation 2 :

$Y_{i}^{*}=\beta_{0}+X_{i}^{T} \beta+\varepsilon_{i}$,

where $\varepsilon_{i} \sim \operatorname{Logistic}(0,1), \beta_{0}$ is the intercept term, and $\beta=\left(\beta_{1}, \beta_{2}, \ldots, \beta_{p}\right)^{T}$ is the vector of regression coefficients. That is, the latent variable $Y_{i}^{*}$ is written as the sum of a linear predictor function $\beta_{0}+X^{T} \beta$ and an error term that follows a standard logistic distribution (Greene 2018).

Then we can derive the formulae for the adoption probability, $P\left(Y_{i}=1\right)$, the odd, $P\left(Y_{i}\right.$ $=1) / P\left(Y_{i}=0\right)$, and the logit expression, $\ln \left(\frac{P\left(Y_{i}=1\right)}{1-P\left(Y_{i}=1\right)}\right)$, as the following:

$P\left(Y_{i}=1\right)=\frac{e^{\beta_{0}+X_{i}^{T_{\beta}}}}{1+e^{\beta_{0}+X_{i}^{T} \beta}}$,

Odd $d_{i}=P\left(Y_{i}=1\right) / P\left(Y_{i}=0\right)=e^{\beta_{0}+X_{i}^{T} \beta}$, and (4)

Logit $_{i}=\ln \left(\frac{P\left(Y_{i}=1\right)}{1-P\left(Y_{i}=1\right)}\right)=\beta_{0}+X_{i}^{T} \beta$.

In the logit model, the logit is modeled as a linear function as in equation 5. For clarity, we can suppress the subscript $i$ in equation 5 and obtain equation 6 :

Logit $=\ln (O d d)=\beta_{0}+X^{T} \beta$.

One small unit change in the $j$-th explanatory variable, holding other variables unchanged, will have the marginal effect of $\beta_{j}$ on the logit, i.e., $\log$ transformation of the odd. Denote the odds ratio $(\mathrm{OR})$ as $\mathrm{OR}=$ Odd $d_{\text {affer }} / \mathrm{O} d d_{\text {before }}$, we have equation 7:

$\ln (\mathrm{OR})=\ln \left(\right.$ Odd $\left._{\text {affer }}\right)-\ln \left(\mathrm{Odd}_{\text {before }}\right)$

$=$ Logit $_{\text {affer }}-$ Logit $_{\text {before }}=\beta_{j}$.

Therefore, OR $=e^{\beta j}$. The coefficient vector is estimated using Maximum Likelihood Estimation (MLE), and the statistical inference is conducted based on the statistical properties of MLEs (Long 1997; Hosmer and Lemeshow 2000). Denote the MLE estimator of $\beta$ as $\hat{\beta}$. According to the invariant property of MLE, the MLE estimator of odds ratio can be estimated as (OR) $\widehat{\mathrm{OR}}=e^{\hat{\beta}_{j}}$ (Greene 2018; Hastie et al. 2009). Testing the significance of $\beta_{j}$ from 0 , i.e., $\beta_{j}=0$ is equivalent to testing the significance of odds ratio from 1, i.e., $\mathrm{OR}=1$. The two tests share the same $p$-value and significance level (Hosmer and Lemeshow 2000; Greene 2018). We conducted logistic regression using logit function STATA software (version 15.0). Estimation and statistical inference were implemented using STATA software (StataCorp 2017).

Survey Description. The mail survey was conducted in three states of the Northern Great Plains, i.e., North Dakota, South Dakota, and Nebraska, to understand agricultural producers' perceptions of water quality problems in their local areas and the conservation practices they adopted to improve soil health and water quality. We conducted the survey from January to March in 2018 utilizing the Dillman Method (Dillman et al. 2014), which involved an advance letter and two mailings of survey questionnaires, followed by a reminder or thank you letter after each mailing of survey questionnaire. In addition to the hardcopy survey questionnaire, recipients were also provided with the option to complete the survey online. We obtained the producer addresses from publicly available online sources, including federal farm subsidy databases, White Pages, and Manta. Together, we had 3,218 farmer addresses, with 877, 1,314, and 1,027 addresses from North Dakota, South Dakota, and Nebraska, respectively. The survey sample contained 3,177 eligible addresses from the sample of a 2016 farm survey (Wang et al. 2019), plus 41 additional addresses supplied by university students, extension specialists, and researchers from USDA.

Among the selected survey samples, 79 were categorized as ineligible due to reasons such as no longer farming, undeliverable, or deceased. Of the 3,139 eligible samples included in the surveys, 620 (19.8\%) responded, and 574 completed the survey questionnaire in a manner that is useful for our analysis, resulting in an effective survey response rate of $18.5 \%$. Overall, our survey response rate is comparable with other published studies that surveyed agricultural producers using generic databases (Fielding et al. 2005; Werner et al. 2017; Wang et al. 2020a). Of those completed surveys, 482 were returned by mail, and 92 were completed online. Among the 574 effective survey responses, 109 (19.0\%), 309 (53.8\%), and 143 (24.9\%) were from North Dakota, South Dakota, and Nebraska, respectively, while $13(2.3 \%)$ did not provide the unique IDs that link with the states.
While publicly available sources offer free and readily available farm addresses, a limitation is that no preselection criteria could be imposed. To evaluate the representativeness of our survey sample in each of the study states, we compared respondent information with state average information in the 2017 Agricultural Census (USDA NASS 2017). Respondent average ages in North Dakota, South Dakota, and Nebraska were 62.2, 61.7, and 65.9 years respectively, compared with the state average principal operator ages of $57.6,57.8$, and 57.8, respectively. On average, respondents reported farm acres of 3,297, 1,649, and 1,286 (1,334, 667.3, and 520.4 ha), respectively, for North Dakota, South Dakota, and Nebraska. This is greater than the average farm acres of 1,492, 1,443, and 971 (603.8, 584, and 392.9 ha) in North Dakota, South Dakota, and Nebraska, respectively, as calculated using total operated acres divided by total number of operations in each state according to USDA NASS (2017). These findings indicate our survey respondents were on average older and operating more area when compared to the state average data.

Data Description. The survey inquired producers on how compromised water quality in their local areas had affected their lives in various aspects. We summarized the potential issues listed in the questionnaire into two major categories in table 1 , comprising (1) environment and recreation issues, and (2) health and economic issues. Six issues were listed under the first category, which are (1) excessive aquatic plants; (2) excessive algal bloom; (3) decline in water birds and wild animals; (4) polluted swimming areas; (5) fishing; and (6) canoeing, kayaking or boating. Similarly, six health and economic issues caused by poor water quality were included in the second category, namely (1) health problems, (2) water in the local area no longer suitable for drinking, (3) fish in the local area no longer suitable for eating, (4) death of livestock, (5) decrease of property values, and (6) negative impact on tourism. For each issue, producers can choose one of the four categories: $0=$ not a problem; $1=$ slight problem; 2 = moderate problem; or 3 $=$ severe problem.

To examine farmers' adoption decisions on cover crops and buffer strips as well as effects of influential factors, we recoded the 5 -scale choices on cover crops and buffer strips to two dummy variables, with $1=$ 


\section{Table 1}

Description of water quality related issues and mean value comparison among states.

\begin{tabular}{|c|c|c|c|c|c|}
\hline \multirow[b]{2}{*}{ Category } & \multirow[b]{2}{*}{ Issue } & \multirow[b]{2}{*}{ Description } & \multicolumn{3}{|l|}{ Mean value } \\
\hline & & & North Dakota & South Dakota & Nebraska \\
\hline \multirow{6}{*}{$\begin{array}{l}\text { Environment and } \\
\text { recreation issues }\end{array}$} & 1 & Excessive aquatic plants & $0.718 b$ & $1.325 a$ & $1.230 \mathrm{a}$ \\
\hline & 2 & Excessive algal bloom & $1.010 \mathrm{~b}$ & $1.426 a$ & $1.106 b$ \\
\hline & 3 & Decline in water birds and wild animals & $0.418 b$ & $0.848 a$ & $0.719 a$ \\
\hline & 4 & Polluted swimming areas & $0.752 b$ & $1.287 a$ & $1.000 \mathrm{ab}$ \\
\hline & 5 & Fishing & $0.714 b$ & $1.153 a$ & $0.970 a b$ \\
\hline & 6 & Canoeing/kayaking/boating & $0.558 \mathrm{~b}$ & $1.047 a$ & $0.940 a$ \\
\hline \multirow[t]{6}{*}{$\begin{array}{l}\text { Health and } \\
\text { economic issues }\end{array}$} & 7 & $\begin{array}{l}\text { Health problems (e.g., allergic reactions, } \\
\text { skin rashes, eye irritations, stomach illness) }\end{array}$ & $0.889 a$ & $1.147 a$ & $1.148 a$ \\
\hline & 8 & Stopped drinking water from my area & $0.248 b$ & $0.690 a$ & $0.615 a$ \\
\hline & 9 & Stopped eating fish or shellfish from my area & $0.376 b$ & $0.727 a$ & $0.687 a$ \\
\hline & 10 & Livestock death & $0.686 a b$ & $0.881 a$ & $0.564 b$ \\
\hline & 11 & Decrease in property values & $0.337 b$ & $0.824 a$ & $0.526 b$ \\
\hline & 12 & Negative impact on tourism & $0.515 b$ & $1.036 a$ & $0.807 a b$ \\
\hline
\end{tabular}

Notes: $0=$ not a problem, $1=$ slight problem, $2=$ moderate problem, and $3=$ severe problem. Letters are used to denote Duncan's multiple range test results, where the same letter implies no statistically significant difference among the average values of the three states at $p<0.05$. The top three most severe water quality issues for each state are in bold.

"currently using" and $0=$ "never heard of," "somewhat familiar," or "know how to use but do not use." We excluded the observations where farmers who regarded cover crops or buffer strips as "not applicable" on their farms in the corresponding regression models. Table 2 provides descriptions of the explanatory variables used in the regression models. Based on factor types, we divided them into four broad categories. Several survey questions were asked to gather information associated with farmer characteristics including farmer age, education level, and gender. Among these, farmer age is a continuous variable, whereas the education level is a binary variable that takes the value 1 for those who have some college, college degree, or above and the value 0 for those who have some high school or high school degree. Gender is also a binary variable, with 1 and 0 standing for male and female, respectively.

Under the farm characteristics and management category, we considered five variables, namely land ownership and size, livestock ownership, and adoption status of conservation tillage (CT) and diversified crop rotation (DCR). Survey respondents were asked about the type of land ownership with three options, namely tenant, both, and owner, denoted as 1,2, and 3, respectively. Livestock ownership and adoption status of $\mathrm{CT}$ and DCR are binary variables that take two values with $1=$ yes and $0=$ no.

Other than the farmer and farm characteristics categories, we also included the information and perception category to cap- ture farmers' information sources, perceptions of water pollution sources and consequences, and motivations/concerns toward adoption of cover crops and buffer strips. Respondents were inquired on their degree of recognition on nine listed information sources on water quality, including (1) friends and neighbors, (2) lead farmers, (3) farm associations, (4) consultants, (5) farm supply dealers, (6) water associations, (7) university extension service, (8) government agencies, and (9) nongovernmental organizations. We considered an information source as important to the respondents (=1) if "moderately" or "very much" was chosen, or not important to them $(=0)$ if "not at all" or "slightly" was chosen. We then added up the number of information sources that producers considered as important, referred to as "information source" in table 2, which provides an indicator on how concerned and/or knowledgeable the respondents were about water quality.

In the information and perception category, we also asked producers about their perceptions of $\mathrm{N}$ as a water pollutant in their areas. Respondents could choose one of the four options: 1 = "not a problem," 2 = "slight problem," 3 = "moderate problem," or $4=$ "severe problem." To capture producers' perceptions of water quality related issues in their region, we converted the two major categories listed in table 1 into two perception variables in table 2 , namely (1) environment and recreation and (2) health and economy. Specifically, the number of issues that respondents perceived as "moder- ate problem" or "severe problem" under each of the two categories were used as indicators of the severity of water quality issues.

The survey also inquired about producers' motivators on cover crop adoption, namely, being motivated by others who already practiced them, referred to as "follower attitude," and being motivated by evidence of economic benefits of these practices, referred to as "profit priority" (table 2). A total of five options were provided on the level of agreement or disagreement about these two motivators, namely "strongly disagree," "disagree," neither agree nor disagree," "agree," and "strongly agree," denoted by 1 through 5 , respectively. Additionally, we inquired producers about their perceived constraints for buffer strip adoption. Specifically, producers were asked to provide a "yes" or "no" answer (= 1 or 0 , respectively) for two issues: whether high expenses limited respondents' ability to adopt buffer strips, and whether respondents considered buffer strips as suitable on their farms.

Lastly, we included the region category to examine potential regional heterogeneity in producers' decisions. Among the three states, two dummy variables for South Dakota and North Dakota were included as regional variables. Both variables take the value of 1 if the respondents are located in the specified state or 0 otherwise.

\section{Results and Discussion}

Perception Difference on Water Quality Related Issues among States. Table 1 dis- 
Table 2

Description of explanatory variables used in the logistic models.

\begin{tabular}{|c|c|c|c|c|c|}
\hline Category & Variable & Description & $\mathbf{N}$ & Mean & SD \\
\hline Farmer & Age & Respondent age & 504 & 62.867 & 12.049 \\
\hline \multirow[t]{2}{*}{ characteristics } & Education & $\begin{array}{l}\text { Highest education level of the respondent ( } 1 \text { = some college, college degree } \\
\text { or above; } 0=\text { high school degree or below) }\end{array}$ & 511 & 0.479 & 0.500 \\
\hline & Gender & Gender of the respondent $(1=$ male; $0=$ female $)$ & 517 & 0.928 & 0.258 \\
\hline Farm & Ownership & Type of farmland ownership ( 1 = tenant; 2 = both; 3 = owner) & 543 & 2.390 & 0.565 \\
\hline characteristics & Acre $\left(\times 10^{3}\right)$ & Total acres of farmland & 492 & 1.886 & 2.756 \\
\hline \multirow[t]{3}{*}{ and management } & Livestock & Ownership of livestock ( 1 = yes; $0=$ no) & 570 & 0.689 & 0.463 \\
\hline & $\overline{\mathrm{CT}}$ & Adoption of conservation tillage (CT) $(1=$ yes; $0=$ no $)$ & 498 & 0.797 & 0.402 \\
\hline & $\overline{\mathrm{DCR}}$ & Adoption of diversified crop rotation $(\mathrm{DCR})(1=$ yes; $0=$ no $)$ & 484 & 0.773 & 0.420 \\
\hline \multirow[t]{8}{*}{$\begin{array}{l}\text { Information and } \\
\text { perception }\end{array}$} & $\begin{array}{l}\text { Information } \\
\text { source }\end{array}$ & $\begin{array}{l}\text { Number of water quality information sources perceived as important by } \\
\text { respondent ( } 0 \text { to } 9)\end{array}$ & 448 & 2.748 & 2.486 \\
\hline & Nitrogen & $\begin{array}{l}\text { Nitrogen as a water pollutant in respondent's area }(1=\text { not a problem; } 2= \\
\text { slight problem; } 3=\text { moderate problem; } 4=\text { severe problem })\end{array}$ & 442 & 2.075 & 0.847 \\
\hline & $\begin{array}{l}\text { Environment } \\
\text { and recreation }\end{array}$ & $\begin{array}{l}\text { Number of moderate/severe water quality problems related to environment } \\
\text { and recreation issues ( } 0 \text { to } 6 \text { ) }\end{array}$ & 497 & 0.976 & 1.595 \\
\hline & $\begin{array}{l}\text { Health and } \\
\text { economy }\end{array}$ & $\begin{array}{l}\text { Number of moderate/severe water quality problems related to health and } \\
\text { economy issues ( } 0 \text { to } 6 \text { ) }\end{array}$ & 503 & 0.463 & 1.091 \\
\hline & $\begin{array}{l}\text { Follower } \\
\text { attitude }\end{array}$ & $\begin{array}{l}\text { Adopt soil conservation practices because others are practicing them }(1= \\
\text { strongly disagree, } 2 \text { = disagree, } 3=\text { neither agree nor disagree, } 4=\text { agree, } 5= \\
\text { strongly agree) }\end{array}$ & 524 & 2.513 & 0.800 \\
\hline & Profit priority & $\begin{array}{l}\text { Need evidence of economic benefits to adopt soil conservation practices }(1= \\
\text { strongly disagree, } 2 \text { = disagree, } 3=\text { neither agree nor disagree, } 4=\text { agree, } 5= \\
\text { strongly agree) }\end{array}$ & 524 & 2.906 & 1.017 \\
\hline & Cost limit & High cost limiting respondent's ability to adopt buffer strip ( $1=$ yes, $0=$ no) & 484 & 0.345 & 0.476 \\
\hline & $\begin{array}{l}\text { Suitability } \\
\text { concern }\end{array}$ & Buffer strip considered suitable for respondent's farm ( $1=$ yes, $0=$ no) & 484 & 0.448 & 0.498 \\
\hline \multirow[t]{2}{*}{ Region } & South Dakota & Respondent from South Dakota $(1=$ yes, $0=$ no) & 570 & 0.547 & 0.498 \\
\hline & North Dakota & Respondent from North Dakota $(1=$ yes, $0=$ no) & 570 & 0.195 & 0.396 \\
\hline
\end{tabular}

plays the average value for each water quality related issue, grouped by state, to compare producers' perception differences at the state level. We also conducted Duncan's multiple range tests for all listed issues, with different letters denoting statistically different results among the three states. Of the three states, South Dakota producers generally regarded the water quality related issues as more severe than the producers located in the other states. On the contrary, North Dakota producers provided significantly lower ratings on most of the water quality issues than those from South Dakota and Nebraska. On average, South Dakota producers provided ratings of greater than 1 ("slight problem") for 7 out of 12 issues listed, while those from North Dakota only provided similar ratings for 1 issue. Nebraska farmers' perceptions were in the middle, with 4 out of 12 issues rated as more than a slight problem.
The issues under the environment and recreation category are largely related to water appearance and associated water activities, and these issues could be readily discerned even at the early stage of water pollution. Most issues under the health and economy category, however, generally take a longer time to fully manifest, and therefore they are generally unobservable unless the water pollution is already a serious problem. As a result, we can see that the issues rated as more than a slight problem under the former category outnumbered those under the latter category for all the three states. The top three issues for all states include excessive aquatic plants and algal bloom, and both issues are caused by high levels of $\mathrm{N}$ in water (Strock et al. 2004; Suplee et al. 2009).

Nevertheless, even under the first category, no issue received a rating of greater than 1.5. This indicates that while most producers, especially those in South Dakota, started to realize water related issues in different aspects, no issue listed was considered as serious as a moderate problem in the surveyed states. This suggests water quality issues are not of paramount concerns in the Northern Great Plains. By contrast, a study conducted in Mashavera River Basin, Georgia, a hotspot of water quality deterioration, found that $44.6 \%$ of farmers perceived the rivers as polluted, $42.4 \%$ perceived limited swimming activities, and $63.8 \%$ perceived their health at risk due to water pollution (Withanachchi et al. 2018).

Water Pollution Sources and Agreeable Measures to Improve Water Quality. Producers were also asked about their perceptions on water pollution sources in their local areas. Of the five potential sources listed, the two leading pollution sources were fertilizers/pesticides and lawn care chemicals, with $28 \%$ producers viewing them either as a moderate problem or as a severe 
problem (figure 1). However, even though fertilizers and pesticides have been found as an important issue that leads to nonpoint source pollution (Dowd et al. 2008), 29\% of the survey respondents failed to realize it as a pollution source in their local areas. Chemicals used to enhance crop production or grassland maintenance were considered as more important pollution sources than the septic systems and industry discharge, which is possibly linked to the predominant role of agriculture in our study region.

When being asked about their agreement with different types of measures to help improve water quality, nearly half of the producers showed either disagreement (31.8\%) or strong disagreement (14.2\%) toward paying taxes to protect local water quality (figure 2). In comparison, less than $20 \%$ of farmers disagreed (12.7\%) and strongly disagreed $(3.5 \%)$ to implement CPs if it involves additional costs from their pocket. When the option changes from CPs at some cost to CPs at no direct cost to farmers, the percentage of farmers who showed disagreement or strong disagreement further reduced to $8.1 \%$ and $0.2 \%$, respectively. Such a contrast suggests that preventative measures that improve soil health and minimize water pollution from the source could garner more farmer support than curative measures that require tax payment to improve water quality. Additionally, when shifting from CPs at some cost to CPs at no direct cost to farmers, the percentage of farmers who showed agreement or strong agreement increased from $43 \%$ to $70 \%$. This indicates that financial assistance provided for the conservation practices could potentially play an effective role for $27 \%$ out of $70 \%$ producers.

Knowledge and Adoption Status of Cover Crops and Buffer Strips. The rest of this paper, therefore, will be devoted to studying knowledge and adoption status of CPs among farmers and factors potentially affecting farmers' adoption decisions. Specifically, we studied two CPs - cover crops and buffer strips. As indicated in figure 3 , very few respondents indicated that they had never heard of these two practices, and only $7.7 \%$ and $13.5 \%$ of the producers indicated these two practices were not applicable for their farms.

Figure 3 shows that $40.2 \%$ of the respondents adopted cover crops and $36.4 \%$ adopted buffer strips. The finding that more farmers showed interest in cover crops than in buffer

\section{Figure 1}

Farmers' perceptions on water pollution sources in their local areas.

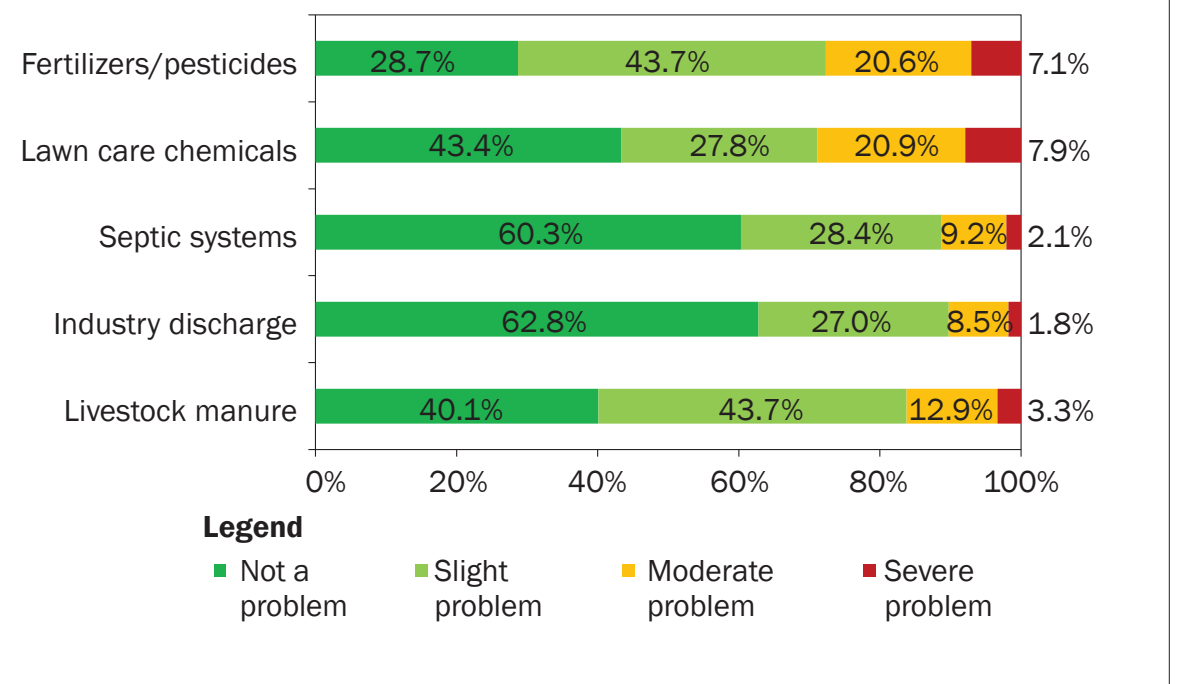

\section{Figure 2}

Farmers' agreement with various efforts to improve water quality ( $\mathrm{CP}=$ conservation practice).

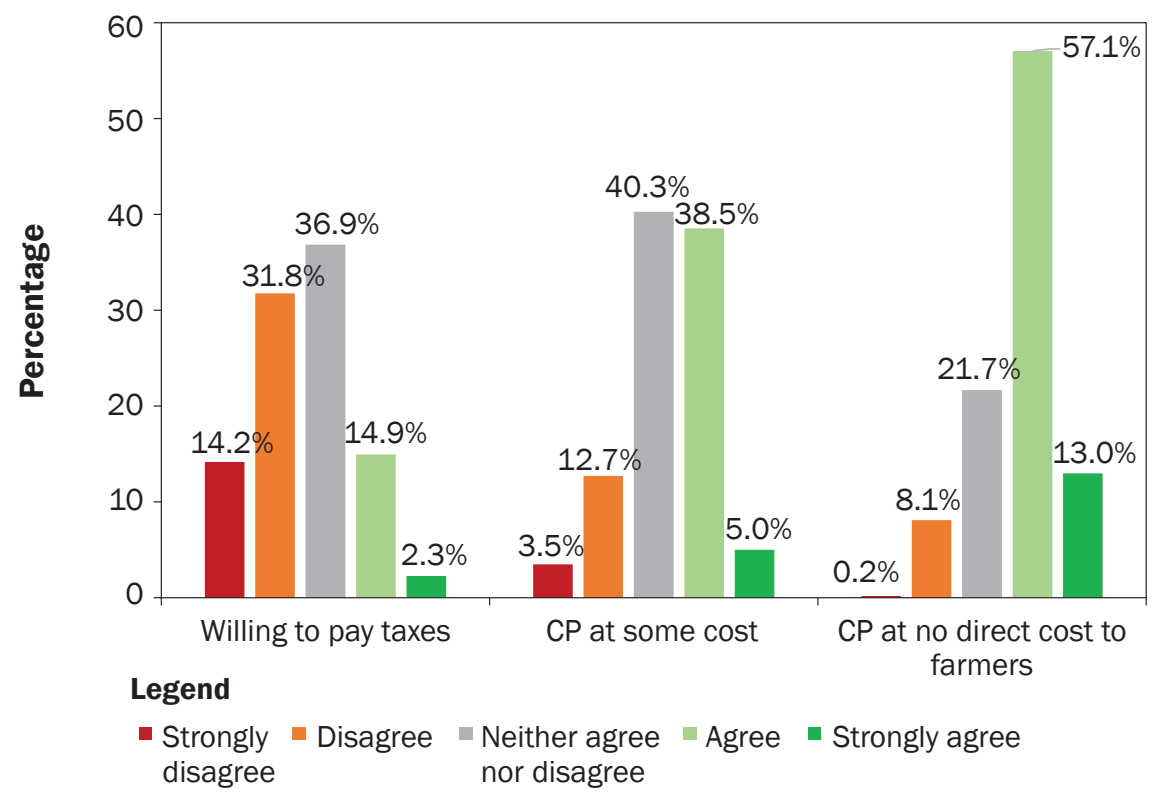

strips is potentially due to the soil and cash crop benefits attributable to cover crops as well as their wider applicability (Eanes et al. 2017). Additionally, $33.0 \%$ and $25.5 \%$ of the respondents identified themselves as knowledgeable nonusers of cover crops and buffer strips, respectively. This implies that among the current nonusers who believed the two CPs applicable for their farms, $63.4 \%$ and
$50.9 \%$ identified themselves as knowledgeable for cover crop and buffer strip practices, respectively, and those people could be considered as the potential target groups to promote these practices.

It is noteworthy that the majority of nonusers indicated they "know how to use but do not use" the practice, which implies lack of knowledge is not the major barrier that 


\section{Figure 3}

Farmers' knowledge and usage status of cover crops and buffer strips.

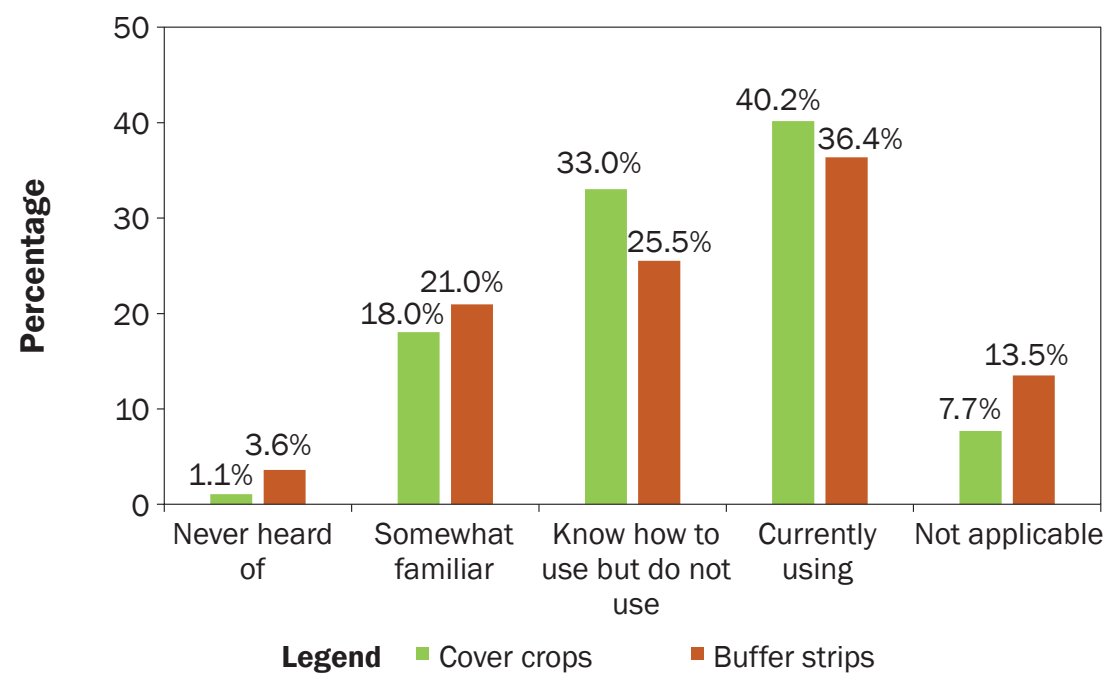

prevents producers from adopting cover crops and buffer strips. For knowledgeable nonusers of cover crops ("know how to use but do not use"), $16.5 \%, 40.8 \%$, and $76.0 \%$ showed agreement (either "agree" or "strongly agree") toward tax payment, CPs at some cost, and CPs at no direct cost to farmers, respectively. Among the current cover crop users, the corresponding percentages for these three choices were 17.4\%, $53.4 \%$, and $70.6 \%$, respectively. A comparison between the preferences of these two groups indicated that a higher percentage of current users indicated willingness to implement CPs at some cost $(53.4 \%)$ when compared to knowledgeable nonusers (40.8\%), while a higher proportion of knowledgeable nonusers expressed agreement for CPs involving no direct cost from farmers $(76.0 \%)$ when compared to current users (70.6\%). Similar differences in agreement levels exist between the knowledgeable nonusers and current users of buffer strips. For those who "know how to use but do not use" buffer strips, $15.4 \%, 45.7 \%$, and $76.1 \%$ showed agreement (either "agree" or "strongly agree") toward tax payment, CPs at some cost, and CPs at no direct cost to farmers. Among the current buffer strip users, the corresponding percentages for those three choices were $21.7 \%, 57.1 \%$, and $73.0 \%$, respectively. Such findings indicate that monetary concerns constitute a primary reason that hinders $\mathrm{CP}$ adoption among knowledgeable nonusers.

Descriptive Statistics. Table 2 demonstrates the descriptive statistics of the explanatory variables used in the cover crop and buffer strip regression models. Under the farmer characteristics category, our result showed that average age of the survey respondents was 62.8 years. On the highest education level achieved, $47.9 \%$ of the survey respondents had some college, college degree, or above, and the rest had either a high school degree or below. As expected with any farmer survey, we found $92.8 \%$ of our survey respondents were male.

Regarding farm characteristics, we found the average ownership score was 2.39 , which indicated that majority of the respondents/ producers had both owned and rented land in their operation. The area of farmland averaged 1,886 ac (763.2 ha). Similar to Wang et al. (2019), average farm size reported by the respondents for this survey was much higher than the average farm size based on the USDA National Agricultural Statistics Service (NASS) census data. We found that the majority of producers (68.9\%) had livestock, which could help enhance cover crop profit by utilizing cover crops for grazing purposes. The adoption rates of CT and DCR were $79.7 \%$ and $77.3 \%$, respectively, indicating that the majority of our survey respondents were current users of one or more CPs.

Eight variables were included under the information and perception category. Regarding information source, the mean value of 2.748 indicates that producers on average considered nearly three out of the nine listed information sources as important.
The average rating for $\mathrm{N}$ is 2.075 , indicating that regarding the role of $\mathrm{N}$ as a potential water pollutant, the survey respondents generally perceived it only as a slight problem in their local regions (table 2). Of all the respondents, only $27.6 \%$ viewed $\mathrm{N}$ pollution as a moderate or severe problem, while the rest perceived it as not a problem or slight problem. For producers who viewed $\mathrm{N}$ pollution as a moderate or severe problem, the adoption rates were $57.9 \%$ and $60.7 \%$ for cover crops and buffer strips, respectively. Adoption rates declined to $40.4 \%$ and $37.0 \%$ for cover crops and buffer strips, respectively, among those who viewed $\mathrm{N}$ pollution as not a problem or slight problem. This indicates that those who realize $\mathrm{N}$ pollution as a critical issue are much more likely to adopt CPs that prevent nutrient runoff into water bodies. Meanwhile, producers who do not view $\mathrm{N}$ as an important water pollutant could also implement adequate CPs, probably due to other reasons such as soil health concerns.

Table 2 shows the average values for the health and economic issues and the environment and recreation issues were 0.463 and 0.976 , respectively, which indicates that the former was perceived as less severe than the latter. Of the six issues listed under both categories in table 1 , the producers on average regarded less than one issue as a moderate or severe concern. The average ratings for follower attitude and profit priority were 2.513 and 2.906, respectively. This means that while producers demonstrated slight disagreement with both motivations on CP (i.e., cover crops) adoption, they showed more agreement with the economic profit motivation than the follower motivation. About 34.5\% of producers perceived the high cost as a limiting factor for their adoption of buffer strips, yet more producers $(44.8 \%)$ considered buffer strips as not suitable for their farm. Note that figure 3 demonstrates that only $13.5 \%$ reported buffer strips as not applicable for their farm, yet the percentage of farmers who reported buffer strips as not suitable $(44.8 \%$ in table 2) is more than tripled the nonapplicability reporting. Table 2 shows that $54.7 \%$ of the respondents were from South Dakota and $19.5 \%$ from North Dakota, and the rest were from Nebraska.

Logit Model Regression. Table 3 presents logit model estimation results for cover crop and buffer strip adoption decisions. Coefficient and odds ratio for each explanatory variable are reported in table 3 . After 
Table 3

Logistic model estimation results for cover crop and buffer strip adoption.

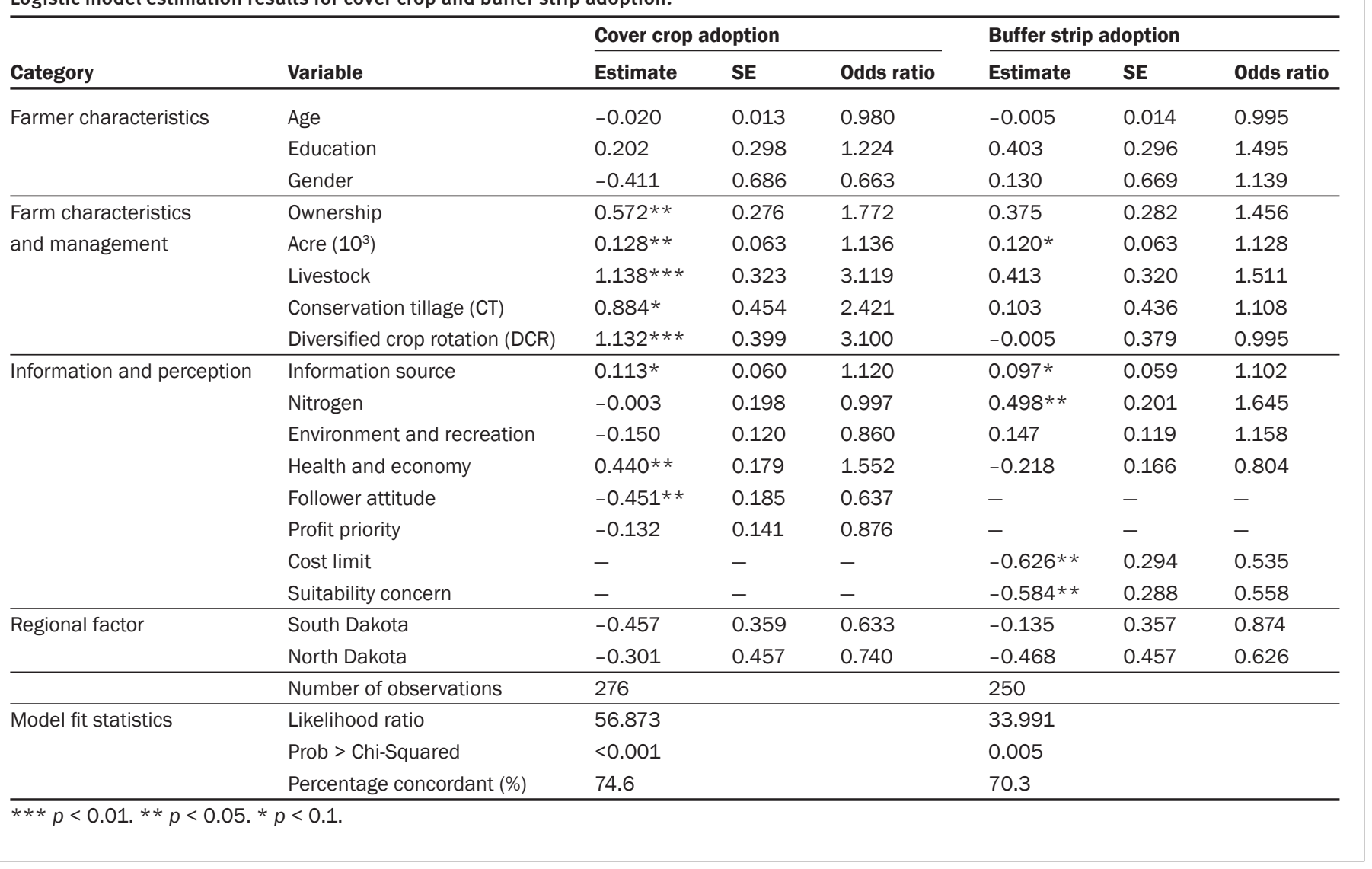

eliminating those observations either with missing values or deemed as nonapplicable for adopting cover crops or buffer strips, logistic regressions were performed using 276 and 250 observations for cover crop and buffer strip adoption, respectively. Log likelihood test was conducted, and the hypothesis that all coefficients are zero was rejected at $1 \%$ significance level for both models. The concordant percentages for the cover crop and buffer strip models were $74.6 \%$ and $70.3 \%$, respectively, which indicates a reasonably good fit of the models.

As indicated in table 3, land ownership had a positive effect on cover crop adoption, which indicated that farmers are more likely to adopt cover crops on their owned land. This is consistent with an Alabama row crop study, which showed that farmers with more rented land are less likely to adopt cover crops because of a greater perceived risk to farm income on rental land (Bergtold et al. 2012). Short-term versus long-term considerations are important for cover crop adoption decisions (Bergtold et al. 2017). Producers are more likely to schedule sustainable management plans for a longer time on their owned land, and therefore they will be more likely to adopt CPs, such as cover crops, that generally take a longer term to manifest soil and economic benefits (Soule et al. 2000). The results showed that farmland size has a positive and significant impact on cover crops adoption, with a larger farming area associated with a greater likelihood of planting cover crops. Farm size is often a good indicator of gross revenue, and larger farms can benefit from economies of scale as they can spread the fixed costs associated with the planting and spraying machinery to more area (Fan et al. 2020). A national survey on early adopters of cover crops shows that growing cover crops is feasible on larger farms, and that the cover crop practice is becoming increasingly common in multiple cropping systems (Dunn et al. 2016).

Compared with those who did not own livestock, producers who owned were 3.119 times more likely to use cover crops. This is consistent with literature findings that livestock producers can incorporate cover crops with livestock production and receive short-term economic returns (MCCC 2015; Lazarus and Keller 2018; Wang et al. 2020b).
Similarly, for adopters of CT and DCR practices, the likelihoods of using cover crops were 2.421 and 3.100 greater, respectively, than the nonadopters. The plausible reasons underlying this finding could be that farm CPs are complementary in nature and joint adoption increases crop yield and farm profit (Teklewold et al. 2013; Prokopy et al. 2019), and that producers who are conservation-minded are likely to try a combination of CPs to achieve maximum soil benefits (Schimmelpfennig and Ebel 2016; Bergtold et al. 2017). Similarly, Lee and McCann (2019) also found that producers using CT and DCR were more likely to utilize cover crops in soybean (Glycine $\max$ [L.] Merr.) production. Incorporating cover crops may be easier for producers who have already practiced CT because of available equipment. For instance, no-till producers already have the no-till drills and planters to handle cover crop residues, while additional expenses on relevant equipment may impede conventional tillage growers from planting cover crops (Grisso et al. 2009; Mirsky et al. 2013). In addition, producers planting a variety of crops may be more open to try cover crops 
because they have more relevant equipment and experience with different crops compared to the monoculture farmers (Singer et al. 2007; Arbuckle and Roesch-McNally 2015). Research findings show cover crops have been considered as critical and consistent components of DCR in the US Corn Belt (Singer et al. 2007).

Farmers who deemed more information sources as important in obtaining water quality information are more likely to adopt cover crops. More information about water quality enables producers to be more aware of water pollution (Eanes et al. 2017), which encourages them to take actions including adopting farm CPs in agricultural production (Prokopy et al. 2008; Arbuckle and Roesch-McNally 2015). Among the nine listed information sources, neighbors and friends may provide their opinions based on personal experience. Dealers, consultants, extension personnel, and associations may provide technical support and scientific evidence regarding how water quality problems can be dealt with in the area (Bergtold et al. 2012; Eanes et al. 2017; Prokopy et al. 2019). Government may provide cost shares to cover crop adopters, which is an important factor to account for when farmers make CP adoption decisions (Myers et al. 2019).

The number of issues farmers perceived as a moderate or severe problem under the health and economy category shows a positive effect on cover crop adoption. Specifically, when the perceived number of moderate and severe issues increase by 1 , farmers are 1.552 times more likely to adopt cover crops. This suggests that producers who are more aware of the negative consequences of water pollution on health and economy related issues are more likely to plant cover crops. On the contrary, for those who show more agreement with CP adoption because others are practicing them, the likelihood of using cover crops is 0.637 times less likely. Currently, cover crop use is still a relatively new practice with low statewide adoption rates, e.g., the number of cover crop users only account for $10.3 \%$ of the total crop operations in South Dakota as of 2017 (USDA NASS 2017). This also echoes the low adoption rate in the semiarid Northern Great Plains (Wade et al. 2015). Therefore, most of the respondents probably know more nonadopters than adopters of cover crops. Consequently, producers with the follower attitude at this stage probably would more likely follow the conventional practice of no cover crops. In this case, one farmer's adoption decision generates a positive externality, since it would likely motivate some neighbors with the follower mentality to adopt. Our finding in this regard supports the suggestions of previous research that government initiatives on improving adoption of CPs should target the early adopters (Reimer et al. 2012; Perry-Hill and Prokopy 2014).

Table 3 also presents the regression results of buffer strip adoption. Farmland shows a positive effect on buffer strip adoption as when farm size increases by 1,000 ac (404.7 ha), the odds of adopting buffer strips increase by 1.128 . This indicates a large area encourages producers to use some land for buffers that improve local water quality. A synthesis of the literature shows that an average of $33 \mathrm{ft}(10 \mathrm{~m})$ buffer strip can provide an optimal trapping capability and reduce sediment transport (Liu et al. 2008). With a larger farming area, a producer is more willing to allocate a portion of the land to maintain an effective buffer width (Castelle et al. 1994; Rhodes et al. 2018).

Additionally, our results show that more information sources encourage farmers to practice buffer strips. Consistent with the adoption of cover crops and other CPs, adoption of buffer strips needs evidence from neighbors and friends, and some information can better facilitate producers to have access to technical and financial support (Ryan et al. 2003; Helmers et al. 2008; Rhodes et al. 2018). As a major fertilizer used for crop production, excessive $\mathrm{N}$ not utilized by crops has caused the nutrient to accumulate in water bodies (Dabney et al. 2006). We find that for producers who regard $\mathrm{N}$ as a more severe water pollution source, the likelihood of adopting buffer strips is 1.645 times greater. This indicates that as producers' perceived environmental costs of agricultural pollutants increase, they would more likely use buffer strips. Evidence has shown that benefit perceptions and knowledge of environmental impacts can contribute to the adoption of riparian buffers by landowners and producers (Buckley et al. 2012; Rhodes et al. 2018). For example, a field survey in the Spring Creek watershed of central Pennsylvania also confirmed the belief that buffers that lead to positive outcomes would motivate landowners to adopt the riparian buffers (Armstrong and Stedman 2012).
Moreover, producers who placed more concerns on high expenses and suitability of buffer strips are 0.535 and 0.558 times less likely to adopt buffers, respectively. Extra costs or profit loss have been found to be significant barriers for CPs. Therefore, government subsidies are necessary to eliminate producers' concern in this regard and to further promote buffer strip adoption. Producers' concern with the suitability of buffer strips on their farm reveals the importance of technical support on buffer strip implementation in a site-specific manner. For example, Dosskey (2001) concluded that it remains unclear on the degree of pollution reduction to be expected from utilizing buffer strips in agricultural fields. Kreig et al. (2019) also mentioned that the effectiveness of filter strips in trapping water contaminants could be contingent on landscapes, site locations, and presence of tile drains.

Among the explanatory variables, the factors under farm characteristics and management category and those under information and perception category play a major role in cover crop adoption, while variables under information and perception category play a predominant role in buffer strip adoption. The primary reason that farm characteristics barely show any effect on buffer strip adoption could be that the benefits of buffer strips are entirely off-farm, and therefore the adoption decision is more contingent on the cost and perceived suitability. Similar to Wang et al. (2019), we find that information source and producer perceptions are the primary influencing factors on the adoption decisions of both CPs. However, both respondent characteristics and regional heterogeneity play no significant role in producers' adoption decisions of cover crops and buffer strips.

\section{Summary and Conclusions}

Utilizing farmer survey data from the North Great Plains, this paper investigated farmers' perceptions on water quality related issues, water pollution sources, and their agreeable measures to improve water quality. On average, South Dakota producers rated 7 out of 12 issues listed as more than a slight problem, followed by Nebraska producers (4 issues) and North Dakota producers (1 issue). Excessive aquatic plants and algal bloom, attributable to high levels of nutrients in water, were ranked as the top severe issues by producers, yet no issue received a rating of 
greater than 1.5 on a 0 to 3 scale $(0=$ "not a problem," 1 = "slight problem," 2 = "moderate problem," and 3 = "severe problem"). In our studied region, where agriculture plays a dominant role, producers viewed fertilizers/ pesticides and lawn care chemicals as the two leading water pollution sources. This indicates that producers are mindful of both farm and nonfarm related chemical inputs that may pose detrimental effects on water quality (Dosskey 2001; Withanachchi et al. 2018).

Producers generally showed disagreement (31.8\%) or strong disagreement (14.2\%) toward paying taxes to protect water quality, while implementing CPs as alternative measures to improve water quality encountered much less opposition. We then analyzed producers' knowledge and adoption status of cover crops and buffer strips, as well as the factors that affect farmers' adoption decisions. Among the survey respondents, $40.2 \%$ and $36.4 \%$ of the respondents were users of cover crops and buffer strips, respectively, while $33.0 \%$ and $25.5 \%$ of the respondents perceived themselves as knowledgeable of the two practices but had not adopted them yet.

We found that the adoption decision of cover crops, as a CP that generates both on- and off-site benefits, hinges largely on farm characteristics and existing farm management practices. For example, landowners with more farm area are more likely to plant cover crops, possibly due to the longer-term planning horizon and improved economies of scale. Our research further demonstrates the compatibility of livestock ownership with cover crop adoption, which helps increase farm income. By further reducing fertilizer and herbicide expenses, cover crops have also been found as jointly used with CT and DCR. As cover crop use is still largely an emerging farm practice, producers with a follower attitude are more likely to wait rather than adopt at this stage.

Producers who obtain water quality information from a greater number of sources are more likely to be adopters of both practices. Meanwhile, our findings suggest that when producers perceive the water pollution problems in their local areas and realize their farming practices could aggravate the problems, they are more likely to adopt the $\mathrm{CPs}$ to improve water quality. Compared to cover crops, the adoption decisions on buffer strips are more influenced by the perception factors. For example, producers more concerned about extra costs and suitability of buffer strips are less likely to adopt. Our results highlight the importance of outreach efforts to disseminate accessible information on current pollution status of local water bodies, as well as information on the sources of water pollution. Furthermore, our findings show that buffer strip adoption decisions are inhibited by site suitability concerns yet encouraged by information availability, which suggests that besides monetary incentives, technical support is of paramount importance on adoption decisions of CPs that only target the off-site benefits.

While our study provides an enhanced understanding of agricultural producers' perceptions of water quality problems in the US Northern Great Plains and the factors that affect their CP adoption decisions, it has certain limitations that could be further improved by future research. For example, we obtained survey sample from publicly available databases with no prerequisite criteria on farm size and locations. To better understand farmer concerns and reduce nonpoint source pollution in a more cost-effective way, future studies could first identify water pollution hotspots in the study area, and then target the producers in selected watersheds with paramount water quality concerns. Furthermore, CP adoption decisions are typically a sequential process, where producers first obtain information and become knowledgeable, and then implement the practice on their farms. More research could be conducted to better understand CP adoption processes and identify key steps and information sources that could help farmers make accelerated and better-informed decisions to curtail water quality problems.

\section{Acknowledgements}

Financial support for this work was provided by USDANIFA (National Institute of Food and Agriculture), Coordinated Agricultural Projects (CAP) under award number 2016-6800424768. We express our sincere gratitude to Iftekhar Uddin Ahmed Chowdhury (research assistant in Ness School of Management and Economics, Brookings, South Dakota) for his valuable research assistance.

\section{References}

Arbuckle, J.G., and G. Roesch-McNally. 2015. Cover crop adoption in Iowa: The role of perceived practice characteristics. Journal of Soil and Water Conservation 70(6):418-429. https://doi.org/10.2489/jswc.70.6.418. Armstrong, A., and R.C. Stedman. 2012. Landowner willingness to implement riparian buffers in a transitioning watershed. Landscape and Urban Planning 105(3):211-220.

Bergtold, J.S., P.A. Duffy, D. Hite, and R.L. Raper. 2012. Demographic and management factors affecting the adoption and perceived yield benefit of winter cover crops in the southeast. Journal of Agricultural and Applied Economics 44(1):99-116.

Bergtold, J.S., S. Ramsey, L. Maddy, and J.R. Williams. 2017. A review of economic considerations for cover crops as a conservation practice. Renewable Agriculture and Food Systems 34(1):62-76.

Bhargava, D.S. 1994. Dal lake clean-up strategy: An example for others? Environmental Conservation 21(3):269-272.

Blanco-Canqui, H., C. Gantzer, S. Anderson, and E. Alberts. 2004. Grass barriers for reduced concentrated flow induced soil and nutrient loss. Soil Science Society of America Journal 68(6):1963-1972.

Blanco-Canqui, H., T.M. Shaver, J.L. Lindquist, C.A. Shapiro, R.W. Elmore, C.A. Francis, and G.W. Hergert. 2015. Cover crops and ecosystem services: Insights from studies in temperate soils. Agronomy Journal 107(6):2449-2474.

Buckley, C., S. Hynes, and S. Mechan. 2012. Supply of an ecosystem service-Farmers' willingness to adopt riparian buffer zones in agricultural catchments. Environmental Science \& Policy 24:101-109.

Carlson, S., and A. Anderson. 2012. Winter Rye Cover Crop Effect on Cash Crop Yields: Year 3. Ames, IA: Practical Farmers of Iowa. https://practicalfarmers.org/research/. Castellano, M.J., M.J. Helmers, J.E. Sawyer, D.W. Barker, and L. Christianson. 2012. Nitrogen, carbon, and phosphorus balances in Iowa cropping systems: Sustaining the soil resource. Proceedings of the 24th Annual Integrated Crop Management Conference, November 28-29, 2012. Ames, IA: Iowa State University Extension. https://lib. dr.iastate.edu/icm/2012/proceedings/26/.

Castelle, A.J., A. Johnson, and C. Conolly. 1994. Wetland and stream buffer size requirements-A review. Journal of Environmental Quality 23(5):878-882.

Clark, A. 2012. Managing Cover Crops Profitably, 3rd edition. Sustainable Agricultural Research \& Education (SARE) Program Handbook Series, Book 9. College Park, MD: SARE Outreach.

CTIC (Conservation Technology Information Center). 2014. Annual Report 2013-2014 Cover Crop Survey. West Lafayette, IN: CTIC. www.ctic.org/data/ Cover_Crops_Research_and_Demonstration_Cover_ Crop_Survey.

CTIC. 2015. Annual Report 2014-2015 Cover Crop Survey. West Lafayette, IN: CTIC.

CTIC. 2017. Annual Report 2016-2017 Cover Crop Survey. West Lafayette, IN: CTIC.

Dabney, S.M., M.T. Moore, and M.A. Locke. 2006. Integrated management of in-field, edge of-field, and after-field buffers. JAWRA Journal of the American Water Resources Association 42(1):15-24.

Dagel, K.J., S.L. Osborne, and T.E. Schumacher. 2014. Improving soybean performance in the Northern Great 
Plains through the use of cover crops. Communications in Soil Science and Plant Analysis 45(10):1369-1384.

Daniels, R., and J. Gilliam. 1996. Sediment and chemical load reduction by grass and riparian filters. Soil Science Society of America Journal 60(1):246-251.

Dillman, D.A., J.D. Smyth, and L.M. Christian. 2014. Internet, Phone, Mail, and Mixed-mode Surveys: The Tailored Design Method. Hoboken, NJ: John Wiley \& Sons.

Dosskey, M.G. 2001. Toward quantifying water pollution abatement in response to installing buffers on crop land. Environmental Management 28(5):577-598.

Dowd, B.M., D. Press, and M. Los Huertos. 2008.Agricultural nonpoint source water pollution policy: The case of California's Central Coast. Agriculture, Ecosystems \& Environment 128(3):151-161.

Dunn, M., J.D. Ulrich-Schad, L.S. Prokopy, R.L. Myers, C.R. Watts, and K. Scanlon. 2016. Perceptions and use of cover crops among early adopters: Findings from a national survey. Journal of Soil and Water Conservation 71(1):29-40. https://doi.org/10.2489/jswc.71.1.29.

Eanes, F.R., A.S. Singh, B.R. Bulla, P. Ranjan, L.S. Prokopy, M. Fales, B. Wickerham, and P.J. Doran. 2017. Midwestern US farmers perceive crop advisers as conduits of information on agricultural conservation practices. Environmental Management 60(5):974-988.

Fan, Y., Y. Liu, P.B. DeLaune, P. Mubvumba, S.C. Park, and S.J. Bevers. 2020. Net return and risk analysis of winter cover crops in dryland cotton systems. Agronomy Journal 112(2):1148-1159.

Fielding, K.S., D.J. Terry, B.M. Masser, P. Bordia, and M.A. Hogg. 2005. Explaining landholders' decisions about riparian zone management: The role of behavioural, normative, and control beliefs. Journal of Environmental Management 77(1):12-21.

Greene, W.H. 2018. Econometric Analysis, 8th edition. New York: Springer.

Grisso, R.D., D.L. Holshouser, and R.M. Pitman. 2009 Equipment Considerations for No-till Soybean Seeding. Blacksburg, VA: Virginia Cooperative Extension. https://vtechworks.lib.vt.edu/bitstream/ handle/10919/56801/442-456.pdf?sequence $=1$.

Hastie,T., R.Tibshirani, and J. Friedman. 2009. The Elements of Statistical Learning: Data Mining, Inference, and Prediction. New York: Springer.

Hebblethwaite, J.F., and C.N. Somody. 2008. Progress in best management practices. In The Triazine Herbicides. 50 years Revolutionizing Agriculture, ed. H.M. LeBaron, J.E. McFarland, and O.C. Burnside, 501-517. San Diego, CA: Elsevier.

Helmers, M.J., T.M. Isenhart, M.G. Dosskey, S.M. Dabney, and J.S. Strock. 2008. Buffers and Vegetative Filter Strips. Ames, IA: Iowa State University, Agricultural and Biosystems Engineering Publications. https://lib. dr.iastate.edu/abe_eng_pubs/298/.

Hoorman, J.J. 2009. Using cover crops to improve soil and water quality. Lima, $\mathrm{OH}$ : Agriculture and Natural
Resources, The Ohio State University Extension Press. https://ohioline.osu.edu/factsheet/anr-57\#.

Hosmer, D.W., and S. Lemeshow. 2000. Applied Logistic Regression. New York: Wiley.

Khan, M., M. Mobin, Z.Abbas, and S.Alamri. 2018. Fertilizers and their contaminants in soils, surface and groundwater. Encyclopedia of the Anthropocene 5:225-240.

Klapproth, J.C., and J.E. Johnson. 2009. Understanding the Science behind Riparian Forest Buffers: Effects on Water Quality. Blacksburg,VA:Virginia Cooperative Extension. www.pubs.ext.vt.edu/420/420-151/420-151.html.

Knowler, D., and B. Bradshaw. 2007. Farmers' adoption of conservation agriculture: A review and synthesis of recent research. Food Policy 32(1):25-48.

Kreig, J.A., H. Ssegane, I. Chaubey, M.C. Negri, and H.I. Jager. 2019. Designing bioenergy landscapes to protect water quality. Biomass and Bioenergy 128:105327.

Lazarus, W., and A. Keller. 2018. Economic Analysis of Cover Crops on Farms Participating in the Southeastern Minnesota Cover Crop and Soil Health Initiative. St. Paul, MN: University of Minnesota Extension. www. lccmr.leg.mn/projects/2015/finals/2015_04e_UMN_ Economics_CoverCrop.pdf.

Lee, S., and L. McCann. 2019. Adoption of cover crops by US soybean producers. Journal of Agricultural and Applied Economics 51(3):1-18.

Legg, J., and J. Meisinger. 1982. Soil nitrogen budgets. Nitrogen in Agricultural Soils 22:503-566.

Lichtenberg, E. 2004. Cost-responsiveness of conservation practice adoption: A revealed preference approach. Journal of Agricultural and Resource Economics 420-435.

Liu, Z., J. Schieffer, W. Hu, and A. Pagoulatos. 2011. Nonpoint source abatement costs in the Kentucky River Watershed. Selected Paper prepared for presentation at the Agricultural and Applied Economics Association's 2011 AAEA and NAREA Joint Annual Meeting, Pittsburgh, Pennsylvania, July 24-26, 2011.

Liu, X., X. Zhang, and M. Zhang. 2008. Major factors influencing the efficacy of vegetated buffers on sediment trapping:A review and analysis. Journal of Environmental Quality 37(5):1667-1674.

Long, J.S. 1997. Regression Models for Categorical and Limited Dependent Variables. Thousand Oaks, CA: Sage Publications.

MCCC (Midwest Cover Crops Council). 2015. Integrating cover crops in soybean rotations: Challenges and recommendations for the North Central Region. https://mccc.msu.edu/wp-content/uploads/2016/10/ ALL_2015_Integrating-cover-crops-in-soybeanrotations.pdf.

Mirsky, S.B., M.R. Ryan, J.R. Teasdale, W.S. Curran, C.S Reberg-Horton, J.T. Spargo, M.S. Wells, C.L. Keene, and J.W. Moyer. 2013. Overcoming weed management challenges in cover crop-based organic rotational no-till soybean production in the eastern United States. Weed Technology 27(1):193-203.
Montgomery, D.R. 2007. Soil erosion and agricultural sustainability. Proceedings of the National Academy of Sciences 104(33):13268-13272.

Myers, R., A. Weber, and S. Tellatin. 2019. Cover Crop Economics: Opportunities to Improve Your Bottom Line in Row Crops. Sustainable Agriculture Research and Education (SARE) Technical Bulletin. College Park, MD: SARE. www.sare.org/wp-content/uploads/ Cover-Crop-Economics.pdf.

NDDH (North Dakota Department of Health). 2019. North Dakota 2018 Integrated Section 305(b) Water Quality Assessment Report and Section 303(d) List of Waters Needing Total Maximum Daily Loads. Bismarck, ND: North Dakota Department of Health.

NDEQ (Nebraska Department of Environmental Quality). 2016. 2015 Nebraska Water Monitoring Programs Report. Lincoln, NE: Nebraska Department of Environmental Quality.

Nieman, C.L.,A.L. Oppliger, C.C. McElwain, and S.M. Gray. 2018. Visual detection thresholds in two trophically distinct fishes are compromised in algal compared to sedimentary turbidity. Conservation Physiology 6(1): coy044.

Pannell, D.J. 2008. Public benefits, private benefits, and policy mechanism choice for land-use change for environmental benefits. Land Economics 84(2):225-240.

Perry-Hill, R., and L.S. Prokopy. 2014. Comparing different types of rural landowners: Implications for conservation practice adoption. Journal of Soil and Water Conservation 69(3):266-278. https://doi.org/10.2489/ jswc.69.3.266.

Pikul, J.L., L. Hammack, and W.E. Riedell. 2005. Corn yield, nitrogen use, and corn rootworm infestation of rotations in the northern Corn Belt. Agronomy Journal 97(3):854-863.

Plastina, A., F. Liu, F. Miguez, and S. Carlson. 2020. Cover crops use in Midwestern US agriculture: Perceived benefits and net returns. Renewable Agriculture and Food Systems 35(1):38-48.

Prokopy, L.S., K. Floress, J.G. Arbuckle, S.P. Church, F. Eanes, Y. Gao, B.M. Gramig, P. Ranjan, and A.S. Singh. 2019. Adoption of agricultural conservation practices in the United States: Evidence from 35 years of quantitative literature. Journal of Soil and Water Conservation 74(5):520-534. https://doi.org/10.2489/jswc.74.5.520.

Prokopy, L., K. Floress, D. Klotthor-Weinkauf, and A. Baumgart-Getz. 2008. Determinants of agricultural best management practice adoption: Evidence from the literature. Journal of Soil and Water Conservation 63(5):300-311. https://doi.org/10.2489/jswc.63.5.300.

Reimer, A.P., D.K. Weinkauf, and L.S. Prokopy. 2012. The influence of perceptions of practice characteristics: An examination of agricultural best management practice adoption in two Indiana watersheds. Journal of Rural Studies 28(1):118-128.

Rhodes, T.K., F.X.Aguilar, S. Jose, and M. Gold. 2018. Factors influencing the adoption of riparian forest buffers in 
the Tuttle Creek Reservoir watershed of Kansas, USA. Agroforestry Systems 92(3):739-757.

Ryan, R.L., D.L. Erickson, and R. De Young. 2003. Farmers' motivations for adopting conservation practices along riparian zones in a mid-western agricultural watershed. Journal of Environmental Planning and Management 46(1):19-37.

Savci, S. 2012. An agricultural pollutant: Chemical fertilizer. International Journal of Environmental Science and Development 3(1):73.

Scharf, P.C., N.R. Kitchen, K.A. Sudduth, J.G. Davis, V.C. Hubbard, and J.A. Lory. 2005. Field-scale variability in optimal nitrogen fertilizer rate for corn. Agronomy Journal 97(2):452-461.

Schimmelpfennig, D., and R. Ebel. 2016. Sequential adoption and cost savings from precision agriculture. Journal of Agricultural and Resource Economics 41(1):97-115.

SDDENR (South Dakota Department of Environment and Natural Resources). 2020. The 2020 South Dakota Integrated Reports for Surface Water Quality Assessment. Pierre, SD: SDDENR. https://denr.sd.gov/ documents/SD_2020_IR_final.pdf.

Simpkins, W., T. Wineland, R. Andress, D. Johnston, G. Caron, T. Isenhart, and R. Schultz. 2002. Hydrogeological constraints on riparian buffers for reduction of diffuse pollution: examples from the Bear Creek watershed in Iowa, USA. Water Science and Technology 45(9):61-68.

Singer, J., S. Nusser, and C. Alf. 2007. Are cover crops being used in the US corn belt? Journal of Soil and Water Conservation 62(5):353-358.

Soule, M.J., A. Tegene, and K.D. Wiebe. 2000. Land tenure and the adoption of conservation practices. American Journal of Agricultural Economics 82(4):993-1005.

StataCorp. 2017. Stata Statistical Software: Release 15. College Station, TX: StataCorp LLC.

Strock, J.S., P.M. Porter, and M. Russelle. 2004. Cover cropping to reduce nitrate loss through subsurface drainage in the northern US Corn Belt. Journal of Environmental Quality 33(3):1010-1016.

Stutter, M.I., W.J. Chardon, and B. Kronvang. 2012. Riparian buffer strips as a multifunctional management tool in agricultural landscapes: Introduction. Journal of Environmental Quality 41(2):297-303.

Suplee, M.W., V. Watson, M. Teply, and H. McKee. 2009. How green is too green? Public opinion of what constitutes undesirable algae levels in streams. JAWRA Journal of the American Water Resources Association 45(1):123-140.

Teklewold, H., M. Kassie, and B. Shiferaw. 2013. Adoption of multiple sustainable agricultural practices in rural Ethiopia. Journal of Agricultural Economics 64(3):597-623.

Tonitto, C., M. David, and L. Drinkwater. 2006. Replacing bare fallows with cover crops in fertilizer-intensive cropping systems: A meta-analysis of crop yield and $\mathrm{N}$ dynamics. Agriculture, Ecosystems \& Environment 112(1):58-72.
USDA NASS (National Agricultural Statistics Service). 2017. 2017 Census of Agriculture. Washington, DC: USDA. www.nass.usda.gov/Publications/AgCensus/2017/ index.php.

USDA NRCS (Natural Resources Conservation Service). n.d. Buffer Strips: Common Sense Conservation. Washington, DC: USDA NRCS. www.nrcs.usda. gov/wps/portal/nrcs/detail/national/newsroom/ features $/$ ?cid $=$ nrcs143_023568.

USEPA (US Environmental Protection Agency). 2017. National Water Quality Inventory: Report to Congress. Washington, DC: USEPA. www.epa.gov/ waterdata/2017-national-water-quality-inventoryreport-congress.

Wade, T., R. Claassen, and S. Wallander. 2015. Conservation-Practice Adoption Rates Vary Widely by Crop and Region. Economic Information Bulletin No. 147. Washington, DC: USDA Economic Research Service. www.ers.usda.gov/webdocs/ publications $/ 44027 / 56332 \_$eib147.pdf?v $=42403$.

Wang, T., H. Jin, B. Kasu, J. Jacquet, and S. Kumar. 2019. Soil conservation practices adoption in Northern Great Plains: Economic vs. stewardship motivations. Journal of Agricultural and Resource Economics 44(2):404-421.

Wang, T., H. Jin, U. Kreuter, H. Feng, D.A. Hennessy, R. Teague, and Y. Che. 2020a. Challenges for rotational grazing practice: Views from non-adopters across the Great Plains, USA. Journal of Environmental Management 256:109941.

Wang, T., X. Zheng, D. Kolady, J.D. Ulrich-Schad, and D. Clay. 2020b. Cover crops usage in South Dakota: farmer perceived profitability and future adoption decisions. Journal of Agricultural and Resource Economics 46(2):287-307.

Ward, M.H. 2009. Too much of a good thing? Nitrate from nitrogen fertilizers and cancer: President's cancer panelOctober 21, 2008. Reviews on Environmental Health 24(4):357.

Werner, M., E. Wauters, J. Bijttebier, H.-H. Steinmann, G. Ruysschaert, and A. Knierim. 2017. Farm level implementation of soil conservation measures: Farmers' beliefs and intentions. Renewable Agriculture and Food Systems 32(6):524.

Wilson, R., L. Burnett, T. Ritter, B. Roe, and G. Howard. 2013. Farmers, phosphorus and water quality: A descriptive report of beliefs, attitudes and practices in the Maumee Watershed of northwest Ohio. Columbus, $\mathrm{OH}$ :The Ohio State University, School of Environment \& Natural Resources.

Withanachchi, S.S., I. Kunchulia, G. Ghambashidze, R. Al Sidawi, T. Urushadze, and A. Ploeger. 2018. Farmers' perception of water quality and risks in the Mashavera River Basin, Georgia: Analyzing the vulnerability of the social-ecological system through community perceptions. Sustainability 10(9):3062.

Zeimen, M., K. Janssen, D. Sweeney, G. Pierzynski, K. Mankin, D. Devlin, D. Regehr, M. Langemeier, and K.
McVay. 2006. Combining management practices to reduce sediment, nutrients, and herbicides in runoff. Journal of Soil and Water Conservation 61(5):258-267. 